\title{
Preclinical assessment of a novel small molecule inhibitor of tryptophan 2,3-dioxygenase 2 (TDO2)
}

\author{
Stefano Crosignani ${ }^{1}$, Gregory Driessens ${ }^{1}$, Michel Detheux ${ }^{1}$, Benoît Van den Eynde ${ }^{2}$, Sandra Cauwenberghs ${ }^{*}$ \\ From Society for Immunotherapy of Cancer 29th Annual Meeting \\ National Harbor, MD, USA. 6-9 November 2014
}

\section{Introduction}

iTeos leverages the science of LICR to target metabolism of the tumor microenvironment and develops small molecule immunomodulators. TDO2 is a heme-containing enzyme highly expressed in the liver, in specific brain regions and liver/brain tumors. It catalyses the first and rate-limiting step of tryptophan catabolism along the kynurenine pathway and thereby regulates systemic tryptophan levels. Tryptophan (Trp) degradation by TDO2 suppresses anti-tumor immune responses and promotes tumor cell survival.

\section{Methods/results}

Medicinal chemistry optimization following a primary HTS (98,000 compound library) led to the selection of three distinct chemical series. Compounds from all series inhibit kynurenine production with comparable $\mathrm{nM}$ potency compared to the earlier described Welcome compound 680C91 in cellular assays $\left(\mathrm{IC}_{50} 190-450 \mathrm{nM}\right.$ (A172)) and without activity on IDO1 (>100-fold selectivity for TDO2). Compounds with low clearance and half-lives of $>1.5 \mathrm{~h}$ in mice were identified for each of the three series. A compound was selected for further in vivo work due to its high oral bioavailability and long half-life in mice (3.5h). TDO2 inhibition was followed by tryptophan quantification in the blood (vehicle $21.0 \pm 1.1$ versus TDO2 $2_{\mathrm{i}}(60 \mathrm{mg} / \mathrm{kg}) 33.9 \pm 1.51 \mu \mathrm{g} / \mathrm{mL}$ Trp; $\mathrm{n}=10$ mice $/$ group). In a time-course experiment, inhibition of tryptophan degradation lasted up to $16 \mathrm{~h}$ with a dose of $60 \mathrm{mg} / \mathrm{kg}$ consistent with good rodent half-life. TDO2 inhibition in a P815 Mastocytoma tumor model overexpressing TDO2 showed efficacy with the investigational TDO2 $2_{\mathrm{i}}, \mathrm{LM} 10$. Further testing with an iTeos TDO2 compound with good $\mathrm{PK} / \mathrm{PD}$ profile is ongoing on liver tumor models (HCC, liver metastases) as well as glioblastoma. A proprietary

${ }^{1}$ iTeos Therapeutics, Gosselies, Belgium

Full list of author information is available at the end of the article antibody for hTDO2 was generated to screen 15 different human cancer types (60 samples each) for TDO2 protein expression. Differential quantification will allow selection of putative clinical indications for TDO2 treatment in stand-alone or combination with standard of care treatment, vaccination or immune checkpoint inhibition.

\section{Conclusions}

iTeos' drug discovery efforts have generated several scaffold structures for first-in-class TDO2 small molecule inhibitors suitable for in vitro and in vivo validation.

\section{Authors' details}

${ }_{1}^{1}$ iTeos Therapeutics, Gosselies, Belgium. ${ }^{2}$ Ludwig Institute for Cancer Research (LICR, Brussels Branch) and de Duve Institute, Université catholique de Louvain (UCL), Brussels, Belgium.

Published: 6 November 2014

doi:10.1186/2051-1426-2-S3-P196

Cite this article as: Crosignani et al:: Preclinical assessment of a novel small molecule inhibitor of tryptophan 2,3-dioxygenase 2 (TDO2). Journal for ImmunoTherapy of Cancer 2014 2(Suppl 3):P196.

Submit your next manuscript to BioMed Central and take full advantage of:

- Convenient online submission

- Thorough peer review

- No space constraints or color figure charges

- Immediate publication on acceptance

- Inclusion in PubMed, CAS, Scopus and Google Scholar

- Research which is freely available for redistribution 